Тришевський О. I.

\title{
ОБГРУНТУВАННЯ ТА ВИБІР СХЕМ ОХОЛОДЖЕННЯ ВАЛКІВ ЛИСТОПРОКАТНИХ СТАНІВ НА ОСНОВІ МАТЕМАТИЧНОГО МОДЕЛЮВАННЯ ПРОЦЕСІВ ТЕПЛООБМІНУ ВАЛКІВ 3 ПОЛОСОЮ
}

Низька собівартість прокату, в тому числі листового, на початку 90-х років XX століття, забезпечила Україні певну конкурентоспроможність на світовому ринку. Але для того, щоб відповідати високим стандартам якості, прийнятим на Заході, необхідно забезпечувати стабільність параметрів технологічного процесу прокатки листа за рахунок застосування сучасних конструкцій прокатних станів, оснащення їх відповідною контрольно-вимірювальною апаратурою та засобами автоматизації технологічного процесу. Тому питання, пов'язані 3 розглядом сучасних вимог до листопрокатного обладнання, а також вибором на основі теоретичних досліджень процесів моделювання теплообміну валків з металом перспективних схем охолодження прокатних валків, $є$ важливими та актуальними для вирішення подальших завдань розвитку виробництва тонкого гарячекатаного листа в Україні.

В даний час стан листопрокатного виробництва в країні перебуває в жалюгідному стані [1]. Поставлені в Національній програмі розвитку гірничо-металургійного комплексу, включаючи прокатне виробництво, завдання: в тому числі по скороченню часу проходження металу в циклі виробництва; зниження витрати енергії не виконані. В даний час більшість металургійних підприємств України поставляє за кордон, в основному, прокатну заготовку, яка там перекочується в готовий прокат і потім реалізується, але за вищою ціною.

Оскільки прокатне виробництво є основним технологічним переділом, який випускає готову продукцію, допускати подальше відставання вітчизняних технологій та обладнання від світового рівня неприпустимо, так як повністю буде втрачена конкурентоспроможність вітчизняного прокату відповідно на зовнішньому і внутрішньому ринках.

Удосконалення технології прокатки листової продукції в Україні стримується застарілим обладнанням листопрокатних станів. Внаслідок цього спостерігається нестабільність температури листа на виході з валків, що є одним з найважливіших факторів, які суттєво впливають на технологічний процес.

При великій різноманітності конструктивних схем як сучасних ливарно-прокатних агрегатів, так і звичайних станів гарячої прокатки в технологічному циклі прокатки існує ряд характерних ділянок, на яких відбуваються істотні теплообмінні процеси в системі навколишнє середовище-смуга-валок [2]. 3 цих ділянок найбільш важливими та такими, що надають істотний вплив як на якість смуги, що прокочується, так і на енергетичні, а, відповідно, i на економічні показники процесу прокатки, є ділянки осередку деформації, де відбувається безпосередній контакт смуги, що прокочується, з валками.

Метою даної роботи є:

- огляд основних напрямків розвитку новітніх технологій світового рівня, що забезпечують випуск тонколистового прокату високої якості з мінімальними енерговитратами, економічного і конкурентоспроможного для вибору напрямків вдосконалення та модернізації прокатного обладнання і технологій в Україні;

- теоретичне визначення (на основі раніше розроблених моделей) теплового стану валків листових станів гарячої прокатки при різних існуючих і пропонованих перспективних схемах їх охолодження;

- а також виявлення найбільш ефективного для стабілізації теплового стану металу по перетину валків способу подачі охолоджуючої води. 
Огляд літературних матеріалів [3], що стосуються закордонного прокатного обладнання, яке використовується для прокатки листа, показав, що зараз найбільша кількість тонких гарячекатаних листів прокочується на широкосмугових станах (ШСС) з безперервними чистовими групами клітей. У 20 столітті змінилося 5 поколінь ШСС.

До І покоління відносяться стани з масою слябів, близько 10 тон.

На станах II покоління прокочують сляби масою до 30 тон, при потужності приводу тільки горизонтальних валків до 70 МВт. Швидкість прокатки до 20 м / с.

Стани III покоління здатні прокатувати сляби масою до 45 тон, при швидкості прокатки до 23 м / с. Спорудження станів III покоління вимагає занадто великих капіталовкладень, що в даний час в умовах світової кризи і спаду виробництва економічно не виправдане.

Широкосмугові стани IV покоління з'явилися як наслідок енергетичних криз 1974 і 1979 років. Для зниження витрат енергії вони мають більш компактне розташування обладнання, а також знижену масу сляба.

В кінці XX століття вважалося, що тонкі листи товщиною 0,6-1,5 мм необхідно виготовляти холодної прокаткою. Однак, різниця цін однакових по марці і якості гарячекатаних і холоднокатаних листів досягає 20-25\%, тобто в порівнянні з холоднокатаними гарячекатані тонкі листи дешевше на 20-120 дол. / т в залежності від технології виробництва. Така відмінність цін забезпечує, у разі навіть часткового використання споживачем гарячекатаних листів замість холоднокатаних, значний економічний ефект [3]. Необхідно відзначити, що в разі пред'явлення не високих вимог до якості поверхні гарячекатаних тонких листів, ці листи можуть застосовуватися як очищені від окалини, так і не очищені від окалини.

На відміну від станів I-IV поколінь, стани V покоління можуть прокатувати гарячекатаний лист товщиною до 0,7 мм завдяки застосуванню нової технології прокатки. Існує два варіанти технології.

За першим варіантом метал на тонкослябовом ливарно-прокатному агрегаті (ЛПА), розливають в сляби товщиною 50 мм, обжимають в першій кліті до 40 мм (з не застиглою серединою), пропускають через прохідну піч (в якій температура смуги знижується і вирівнюється по перетину).

Після прокатки в чорновій групі метал потрапляє в установку надшвидкісного охолодження для зниження температури до рівня $830^{\circ} \mathrm{C}$. Стверджують [3], що прокатка сталі зі складом 0,04 \% вуглецю, при такій температурі, не приводить до зростання зусилля на валки.

За другим варіантом (рис. 1) використовують проміжне змотування смуги і подачу іiі в чистову групу (заднім кінцем). Така технологія забезпечує рівномірність температури при прокатці в чистовий групі $[4,5]$.

Надтонкі гарячекатані листи можна отримати і на станах IV покоління з низьковуглецевих сталей методом феритної прокатки при температурі початку прокатки в чистовій групі $830{ }^{\circ} \mathrm{C}$. Це дозволяє істотно знизити виробничі витрати за рахунок значного зменшення температури нагріву слябів до $1150{ }^{\circ} \mathrm{C}$. Перехід на низькотемпературну прокатку економить до $20 \%$ енергії.

Феритна прокатка низьковуглецевих сталей дозволяє отримувати надтонкі гарячекатані листи, придатні для штампування деталей кузовів автомобілів, з метою часткової заміни ними холоднокатаних [6]. Так фірма Arcelor зупинила стани холодної прокатки смуги на півночі Франції загальною потужністю 800 тис. тон / рік і планує знижувати виробництво холоднокатаного листа в Північній Свропі [7]. Удосконалення технології прокатки й охолодження дозволяє отримати гарячекатану листову сталь зі стабільними механічними властивостями при прокатці як надтонких, так і товстих листів [8].

Однією з технологій, розроблених компанією "VAI" (Австрія) передбачається аустенітна прокатка листа товщиною 1,5 мм, за традиційною технологією. Після цього смугу змотують в рулон, який передають на окремо розташовану кліть, для прокатки до товщини 0,8 мм в феритній області. Кліть має двигун потужністю 12 МВт і здатна забезпечувати обтиснення до 50 \% при швидкості прокатки з мастилом до 20 м / с. Для встановлення подібного обладнання на діючому стані необхідно 35 млн. дол. США [3]. 


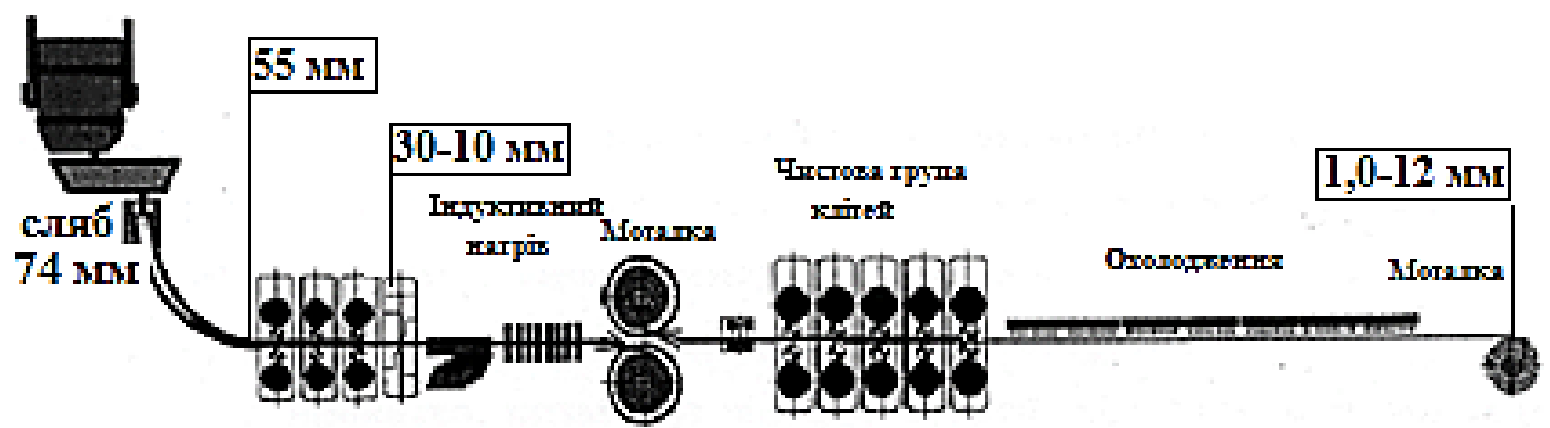

а) Одинарна лінія, ширина листа 1300 мм. Продуктивність 1 млн т / рік

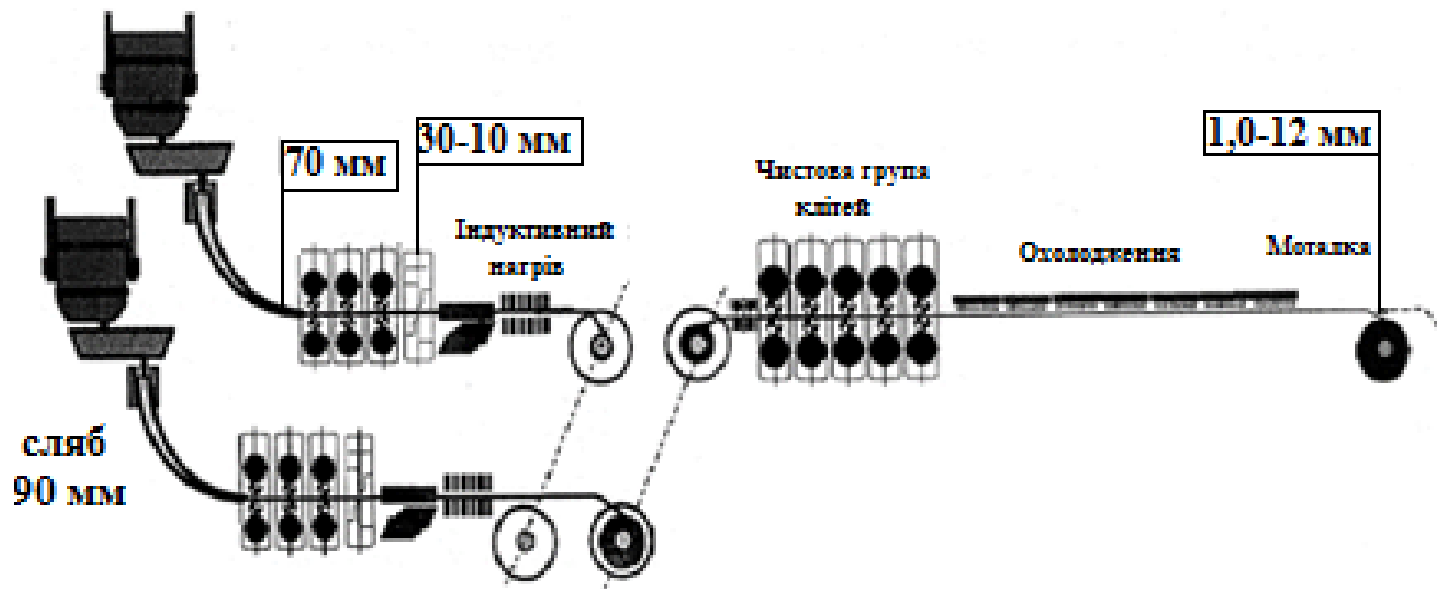

б) Спарена лінія розливки. Ширина листа 1850 мм. Продуктивність 3,2 млн т / рік

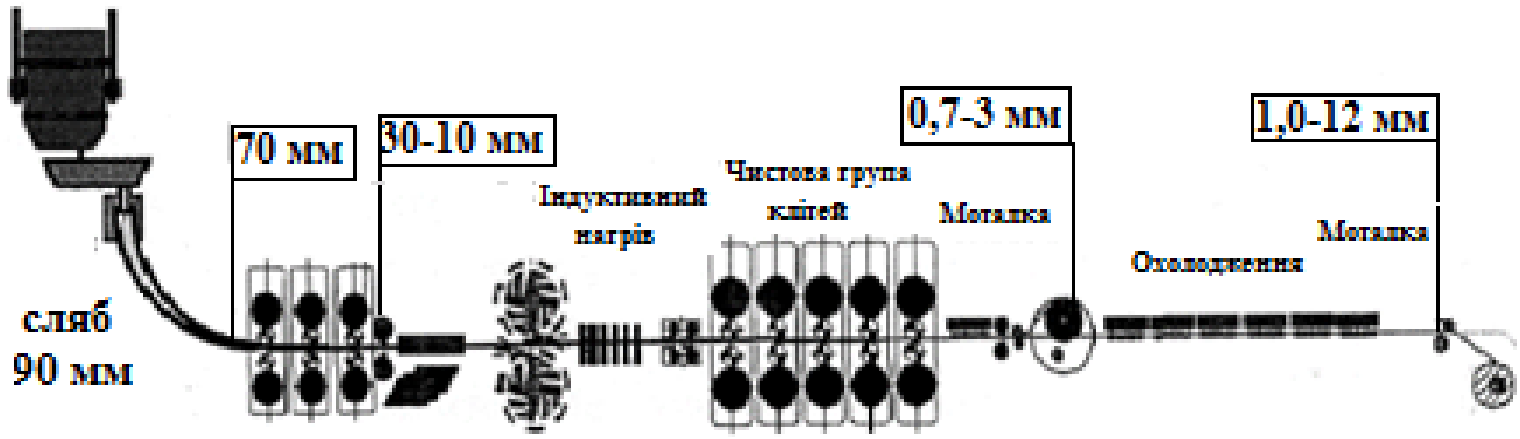

в) Одинарна лінія, ширина листа 1850 мм. Продуктивність 2,5-3,0 млн т. / рік

Рис. 1. Схеми ливарно-прокатних агрегатів фірми Arvedi Stee1 Technology (Кремона, Італія) (a, б, в)

У Голландії на початку 2000 року побудований ЛПА загальною довжиною 450 м при вартості обладнання 283 млн дол. США [4]. Для швидкого охолодження смуги водою змонтована установка довжиною $32 \mathrm{M}$.

Собівартість гарячекатаних листів вироблених на тонкослябових ЛПА виявляється на 50 дол. США / тонну прокату нижче, ніж при прокатці за традиційною технологією. Це пов'язано з меншими витратами на енергію і обслуговування обладнання [5].

У роботах [3, 9-10] наведені опис технологи виробництва надтонких смуг на тонкослябових ЛПА, основою якої $є$ компактні установки надшвидкісного охолодження смуги (Ultra Fast Cooling - UFC), які встановлюються між чорновою і чистовою групами клітей, а також після чистової групи перед моталками. Довжина установки охолодження смуги зменшилася з 60 м (стан 1700 Маріупольського металургійного комбінату ім. Ілліча) [12] до 32 м (ЛПА в Голландії - обладнання поставлено фірмами "SMS - Demag" - Німеччина, "Techint Technologies Italimpianti" - Італія, "Mitsubishi Heavy Ind - Японія) [4] і до 7 метрів на заводі Cockerill-Samre (Франція) [11]. 
Робота ЛПА в безперервному режимі прокатки, особливо при прокатці тонкого гарячекатаного листа, вимагає бездоганних систем охолодження прокатних валків. При цьому витрата води, тиск і спосіб їі подачі повинні відповідати тепловому навантаженні валків.

Відомо, що тепловий стан валків залежить від обраних схем їх охолодження. На рис. 2 наведені існуючі схеми охолодження робочих валків листових станів.

При двосторонньої схемі подачі води на валок (рис. 1, б) між двома зонами примусового охолодження існує ще одна проміжна зона вирівнювання температури.

Необхідно відзначити, що вода, яка потрапляє від валків на поверхню листа при двосторонньої схемі подачі води, охолоджує поверхню смуги перед входом в зону деформації i на виході із зони деформації. Падіння температури поверхні смуги перед входом в зону деформації під впливом охолоджуючої валок води, становить від 2 до $10^{\circ} \mathrm{C}$ в залежності від товщини окалини, що екранує смугу від охолодження. Крім того, коефіцієнт тепловіддачі до води, що знаходиться на паровій подушці, незначний [13]. До того ж, час контакту води з металом, внаслідок високої швидкості прокатки, також незначний.

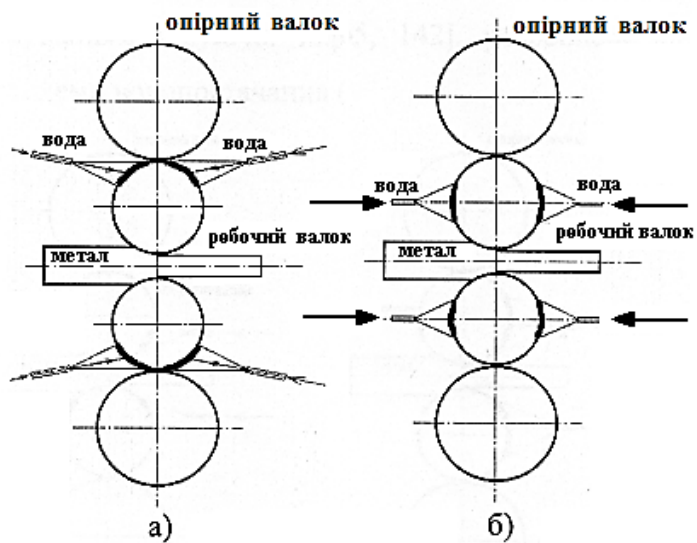

Рис. 2. Існуючі схеми охолодження робочих валків листових станів гарячої прокатки: а) $з$ подачею води з боку протилежного зоні деформації; б) з подачею води 3 двох сторін (двостороння)

Вода, що потрапляє на поверхню листа після виходу смуги із зони деформації, також знаходиться на паровій подушці. Безпосередній контакт між водою та металом - відсутній. Теплообмін на цій ділянці здійснюється через прошарок пара.

3 урахуванням існуючої інформації [4], розроблені перспективна і економічна схеми подачі води (рис. 3).

Перспективна схема (рис. 3, а) розроблена для листових станів і відрізняється тим, що сектор подачі води зміщений в зону деформації смуги. Передбачається застосування перспективної схеми охолодження валків листових станів у клітях реверсивного типу.

Економічна схема охолодження робочих валків (рис. 3, б), розроблена для застосування в безперервних групах листових станів і відрізняється від перспективної місцеположенням пристроїв подачі води. Вона може бути використана, на реверсивних клітях, якщо буде можливість здійснювати реверс подачі води на охолодження одночасно з реверсом валків.

Принциповий вибір схеми охолодження може бути зроблений на основі аналізу теплового стану валка при різних схемах подачі на нього води.

На основі раніше розроблених математичних моделей теплового стану виконані обчислення теплового стану валків при різних умовах охолодження. Довжина зон примусового охолодження для перших трьох схем - однакова. Довжина зони примусового охолодження при економічній схемі подачі води на валки зменшена на 25 \%. При обчисленнях зниженням температури поверхні валка за рахунок теплообміну з повітрям - нехтували, так як коефіцієнт тепловіддачі в повітря дуже низький і становить всього $10-15$ Вт/(м² × град). 


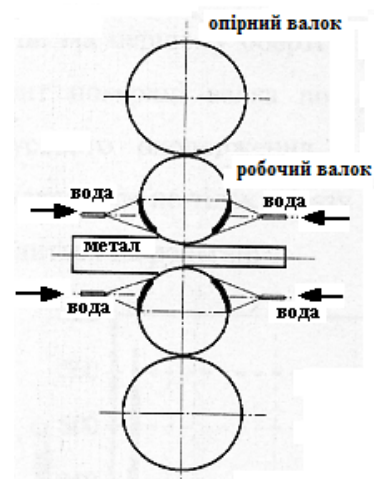

a)

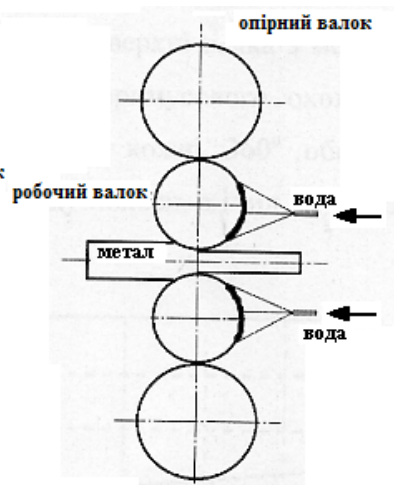

б)

Рис. 3. Розроблені схеми охолодження робочих валків: а) перспективна; б) економічна

На рис. 4 представлені результати обчислення теплового стану валка за один цикл (а не за один оборот) при традиційній (рис. 2, а) схемі подачі води. Всі дослідження виконані для випадку прокатки заготовки листа 5 х $2000 \times 11000$ зі сталі Ст. 3 в чистової кліті стана 2250 Алчевського металургійного комбінату, оскільки на цьому стані з метою з'ясування причин поломок валків був виконаний комплекс досліджень і отримано великий обсяг експериментальних даних [15].

За один цикл прокатки на реверсивному стані валок встигає зробити кілька оборотів. На першому обороті відбувається контакт поверхні валка з металом. Після цього елемент поверхні валка потрапляє в зону примусового охолодження. Початок примусового охолодження здійснюється кожні $360^{\circ}$ оборотів валка. Валок охолоджується не тільки відразу після проходу смуги, але і під час циклу, коли смуга знаходиться на рольгангу.

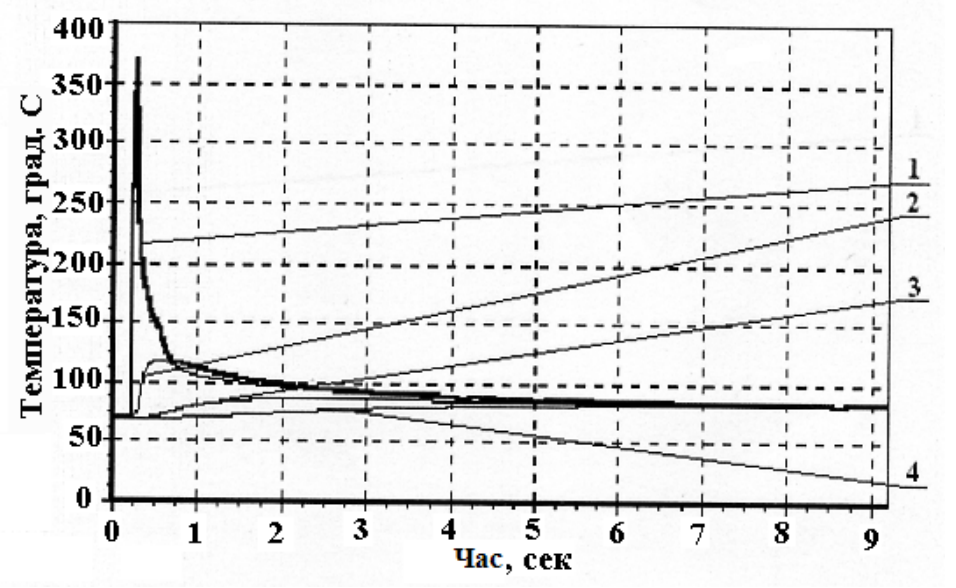

Рис. 4. Температурне поле валка за один цикл:

1 -поверхня; 2 - відстань від поверхні 1,8 мм; 3 - відстань від поверхні 2,2 мм; 4 - відстань від поверхні 3,8 мм

Математична модель [16] дозволяє обчислювати температуру по глибині валка з кроком через кожні 0,001 мм і менше. Але при цьому залежності, що описують тепловий стан внутрішніх шарів валка, при графічному відображенні будуть зливатися. Тому для зручності зображення температурного поля валка обрані: поверхня, і шари, що знаходяться від неї на відстані 1,8 мм, 2,2 мм і 3,8 мм відповідно.

У разі подачі води з боку протилежної зоні деформації (рис. 2, а) зона охолодження практично одна (струмені води подаються на поверхню валка 3 двох сторін практично до лінії контакту з опорним валком). При цьому чергування зон теплообміну за один оборот наступне: - теплообмін з навколишнім середовищем; - зона примусового охолодження; - теплообмін з навколишнім середовищем. 
Результати розрахунку теплового стану валка при двосторонній подачі води (рис. 2, б) дають аналогічні наведеним на рис. 4 для традиційної схеми охолодження результати.

При використанні схеми охолодження з двох сторін, зони теплообміну поверхні валка чергуються в такій послідовності: - теплообмін з навколишнім середовищем; - зона примусового охолодження; - теплообмін з навколишнім середовищем; - зона примусового охолодження; - теплообмін з навколишнім середовищем.

Результати математичного моделювання теплового стану валка при подачі води з боку протилежної зоні деформації і двосторонньої подачі води на валок показують, що в обох випадках відсутня стабілізація теплового стану валка - його температура росте на $11-12^{\circ} \mathrm{C}$ за один цикл.

Результати обчислення теплового стану валка при перспективній схемі подачі води представлені на рис. 5.

При використанні перспективної схеми подачі води на валок зростання температури за один цикл зменшується вдвічі і становить 5-6 ${ }^{\circ} \mathrm{C}$. При цьому було прийнято, що інтенсивність охолодження при всіх трьох розглянутих вище схемах - однакова.

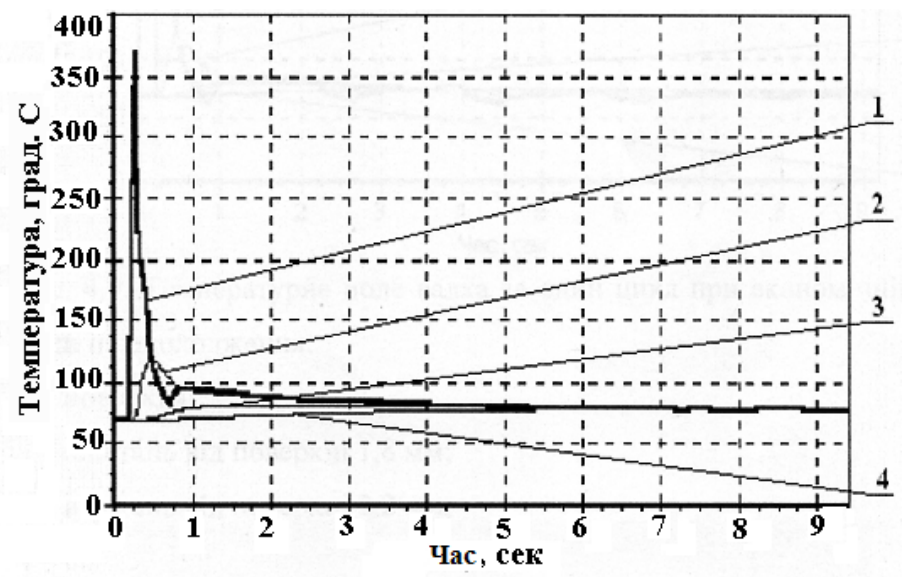

Рис. 5. Температурне поле валка за один цикл при перспективній схемі подачі води на охолодження:

1 - поверхня; 2 -відстань від поверхні 1,8 мм; 3 -відстань від поверхні 2,2 мм; 4 - відстань від поверхні 3,8 мм

Найбільший інтерес представляють результати математичного моделювання теплового стану валка при економічному способі подачі води на валок (рис. 6).

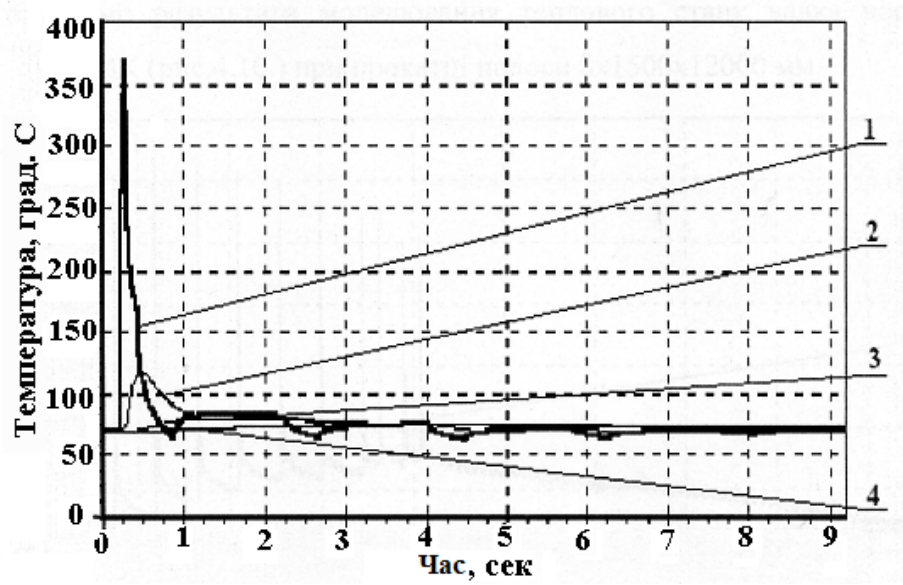

Рис. 6. Теплове поле валка за один цикл при економічній схемі подачі води для охолодження:

1 - поверхня; 2 - відстань від поверхні 1,8 мм; 3 - відстань від поверхні 2,2 мм; 4 - відстань від поверхні 3,8 мм 
Істотна відмінність економічного способу подачі води в тому, що стабілізація температурного поля валка забезпечується при зменшенні на 25 \% (рис. 3, б) довжини зони примусового охолодження. Завдяки цьому, з'являється можливість зменшити кількість води на охолодження. Стійкість валків за рахунок стабілізації теплового стану за даними Маріупольського металургійного комбінату ім. Ілліча підвищується на 10 \%.

Фактичну кількість води, необхідної для забезпечення стабілізації температурного поля валка і ії кількість, що економиться, можна буде встановити після проведення експериментальних досліджень процесу охолодження. Найістотнішим при розробці систем охолодження прокатних валків $\epsilon$ те, що запропоновані схеми (перспективна і економічна) можуть бути використані при проектуванні швидкісних безперервних станів гарячої прокатки п'ятого покоління. Тепловий стан валка може бути однозначно встановлений, якщо достовірно відома температура смуги, яка контактує з валками.

\section{ВИСНОВКИ}

У промислово розвинених країнах (Німеччина, Японія, Франція, США, Італія, Південна Корея) проводяться дослідження технології прокатного виробництва гарячекатаної смуги з метою скорочення витрат на виробництво тони прокату (економія палива, електроенергії, металу) за рахунок скорочення часу технологічного процесу.

Технології прокатки смуги на Україні вимагають істотних змін з урахуванням вимог економії енергії для зменшення собівартості готової продукції шляхом вдосконалення обладнання і режимів обтиснень з урахуванням теплового стану смуги.

На основі математичного моделювання процесів теплообміну валків 3 металом і навколишнім середовищем досліджені різні схеми їх охолодження. Встановлено, що існуючі схеми охолодження валків не забезпечують стабілізації їх теплового стану протягом одного циклу і запропоновані схеми охолодження валків, які можуть забезпечити стабілізацію теплового стану валків у реверсивних клітях і в неперервних групах клітей - перспективну і економічну.

\section{СПИСОК ВИКОРИСТАНОЇ ЛІТЕРАТУРИ}

1. Капланов В. И. Модернизация листопрокатного производства Украины: главные направления развития и перспектива. Вісник Приазовського державного технічного університету. Серія: Технічні науки. Маріуполь. 2011. 22. С. 86-89.

2. Тришевский О. И., Салтавец Н. В. Разработка математической модели теплового состояния полосы при прокатке. Сталь. Москва, 2009. 2. С.42 - 46.

3. Дегнер М., Тамлер Х. У. Новые технические разработки в области горячей прокатки полосы. Черные металль. Москва, 2001. С. 15-17.

4. Матвеев Б. Н. Совершенствование непрерывного производства горячекатаной широкополосной стали. Производство проката. Москва, 2002. С. 17-24.

5. Tomitz A., Kaspar K. Ferritic rolling with additional annealing to produce a deepdrawble ultra-thin-gauge hot strip. Steel Res. 2000. 12(71), pp.497-503.

6. Kvackaj T., Pokorny I. Auto body sheets for a new car generation. Metalurgia. Zagreb 2002. 1(41), pp. $37-42$.

7. C1arкe I. Arce1or reviews CR over-capacity. Metall Bulletin. 2003. 8745, p. 14.

8. Herman J. C. Impact of new rolling and cooling technologies on termomechanically processed steels. Ironmak. And Steelmak. 2001. 2(28), pp. 159-163. pp. 164-169.

9. Porter D. Termomechanical processing on hot strip and plant mills. Ironmak. And Steelmak. 2001. 2(28),

10. Hendricks C., Rasim W., Janssen H. et all. Start-up and initial experience with the castin-rolling plant of Thyssen Krupp Stahl AG. La Revue de Metallurgie. C1T. 2001. 78, pp. 633-666.

11. De Paepe, Simon P., Moerkerke I., Hermann J.C. Control of the temperature of the bar on entry to the finisher. ECSC STEEL RTD PROGRAMME. 2000, pp. 1-9.

12. Антипин В. Г., Нестеров Д. К., Кизиев В. Г. и др. Прокатные станы. Т. 3. Листопрокатные станы и профилегибочные агрегаты. Справочник. Москва: Металлургия, 1992. 428 с.

13. Крейд Ф., Блэк У. Основы теплопередачи. Пер. с англ.Москва: Мир, 1983. 512 с.

14. Stevens P. G., Ivens K. P., Harper P. Increasing work-roll by improved roll-cooling practice. Journal of the Iron Steel Institute. London, 1971. 1, pp. 3-13. 
15. Экспериментальное исследование усилий прокатки в чистовой клети стана 2250. Комитет промышленной политики Украины. ОАО Алчевский металлургический комбинат, ЧК НКП «Аверс». УкрНИИМет. Харьков. 2000. 39 с.

16. Тришевский О. И., Салтавец Н. В. Разработка математической модели теплового состояния валков при прокатке. Сталь. Москва, 2011. 12. С. 22-26.

\section{REFERENCES}

1. Kaplanov V.I. Modernization of sheet-rolling production in Ukraine: main directions of development and prospects. Bulletin of the Azov sovereign technical university. Series: Technical Sciences. Mariupol. 2011. 22, pp. 86-89. (in Russian).

2. Trishevsky O.I, Saltavets N.V. Development of a mathematical model of the thermal state of the strip during rolling. Steel. Moscow. 2009. 2, pp. 42-46. (in Russian).

3. Degner M., Tamler H.W. New technical developments in the field of hot strip rolling. Black metals. Moscow. 2001, pp. 15-17. (in Russian).

4. Matveev B.N. Improving the continuous production of hot rolled broadband steel. Rolled metal production. Moscow. 2002, pp. 17-24. (in Russian).

5. Tomitz A., Kasrar K. Ferritic rolling with additional annealing to produce a deepdrawble ultra-thin-gauge hot strip. Steel Res. 2000. 12 (71), pp. 497-503.

6. Kvackaj T., Pokorny I. Auto body sheets for a new car generation. Metalurgia. Zagreb 2002.1 (41), pp. $37-42$.

7. Clarke I. Arcelor reviews CR over-capacity. Metall Bulletin. 2003. 8745, pp. 14.

8. Herman J.C. Impact of new rolling and cooling technologies on termomechanically processed steels. Ironmak. And Steelmak. 2001. 2 (28), pp. 159-163. pp. 164-169.

9. Porter D. Termomechanical processing on hot strip and plant mills. Ironmak. And Steelmak. 2001. 2 (28),

10. Hendricks C., Rasim W., Janssen H. et all. Start-up and initial experience with the castin-rolling plant of Thyssen Krupp Stahl AG. La Revue de Metallurgie. C1T. 2001. 78, pp. 633-666.

11. De Raere, Simon R., Moerkerke I., Hermann J.C. Control of the temperature of the bar on entry to the finisher. ECSC STEEL RTD PROGRAMME. 2000, pp. 1-9.

12. Antipin V.G., Nesterov D.K., Kiziev V.G. et al. Rolling mills. T. 3. Sheet-rolling mills and roll-forming units. Directory. Moscow: Metallurgy. 1992. 428 p. (in Russian).

13. Craid F., Black W. Basics of heat transfer. Per. from English. Moscow: Mir. 1983. 512 p. (in Russian).

14. Stevens P.G., Ivens K.P., Harper P. Increasing work-roll by improved roll-cooling practice. Journal of the Iron Steel Institute. London. 1971. 1, pp. 3-13.

15. Experimental study of rolling forces in the finishing stand of mill 2250. Industrial Policy Committee of Ukraine. OJSC Alchevsk Metallurgical Plant, Cheka NKP "Avers". UkrNIIMet. Kharkiv. 2000. 39 p. (in Russian).

16. Trishevsky O.I., Saltavets N.V. Development of a mathematical model of the thermal state of the rolls during rolling. Steel. Moscow. 2011. 12, pp. 22-26. (in Russian).

Тришевський О. I. - д-р техн. наук, проф., зав. кафедри ХНТУСГ;

E-mail: 3shev@ukr.net.

Салтавець М. В. - - інженер ХНТУСГ;

Кондращенко В. О. - студент ХНТУСГ.

ХНТУСГ - Харківський національний технічний університет сільського господарства ім. П. Василенка, м. Харків. 